\title{
UCRL-PROC-229951
}

LAW RENCE LIVERMORE N A T IO N A L LABORATORY

\section{Enhanced Corrosion Resistance of Iron-Based Amorphous Alloys}

R. B. Rebak, S. D. Day, T. Lian, L. F. Aprigliano,

P. D. Hailey, J. C. Farmer

April 16, 2007

2007 ASME Pressure Vessels and Piping Division Conference San Antonio, TX, United States July 22, 2007 through July 26, 2007 
This document was prepared as an account of work sponsored by an agency of the United States Government. Neither the United States Government nor the University of California nor any of their employees, makes any warranty, express or implied, or assumes any legal liability or responsibility for the accuracy, completeness, or usefulness of any information, apparatus, product, or process disclosed, or represents that its use would not infringe privately owned rights. Reference herein to any specific commercial product, process, or service by trade name, trademark, manufacturer, or otherwise, does not necessarily constitute or imply its endorsement, recommendation, or favoring by the United States Government or the University of California. The views and opinions of authors expressed herein do not necessarily state or reflect those of the United States Government or the University of California, and shall not be used for advertising or product endorsement purposes. 


\title{
Proceedings of PVP2007 \\ 2007 ASME Pressure Vessels and Piping Division Conference \\ July 22-26, 2007, San Antonio, Texas \\ PVP200726166
}

\section{ENHANCED CORROSION RESISTANCE OF IRON-BASED AMORPHOUS ALLOYS}

\author{
Raul B. Rebak \\ S. Daniel Day \\ Tiangan Lian \\ Louis F. Aprigliano ${ }^{1}$ \\ Phillip D. Hailey \\ Joseph C. Farmer \\ Lawrence Livermore National Laboratory \\ Livermore, California, 94550 USA \\ ${ }^{1}$ Consultant, Berlin, MD, 21811 USA
}

\begin{abstract}
Iron-based amorphous alloys possess enhanced hardness and are highly resistant to corrosion, which make them desirable for wear applications in corrosive environments. It was of interest to examine the behavior of amorphous alloys during anodic polarization in concentrated salt solutions and in the salt-fog testing. Results from the testing of one amorphous material (SAM2X5) both in ribbon form and as an applied coating are reported here. Cyclic polarization tests were performed on SAM2X5 ribbon as well as on other nuclear engineering materials. SAM2X5 showed the highest resistance to localized corrosion in $5 \mathrm{M} \mathrm{CaCl}_{2}$ solution at $105^{\circ} \mathrm{C}$. Salt fog tests of 316L SS and Alloy 22 coupons coated with amorphous SAM2X5 powder showed resistance to rusting. Partial devitrification may be responsible for isolated pinpoint rust spots in some coatings.
\end{abstract}

Keywords: Iron-Based Amorphous Alloys, Corrosion, N06022, Salt Fog Testing, Chloride

\section{INTRODUCTION}

Metallic amorphous alloys or metallic glasses have been studied extensively for the last three decades due to their unique characteristics, including superior mechanical properties and corrosion resistance [1]. To produce an amorphous alloy from a liquid state, cooling rates in the order of $10^{6}$ to 1 degrees Kelvin per second are required, depending on the glass forming ability of the melt [1]. The amorphous alloys are chemically and structurally homogeneous since they do not contain grain boundaries, dislocations and secondary phases, which are common in the crystalline materials [1]. The corrosion resistance of amorphous alloys depends on the alloy composition [2-4]. Amorphous alloys are more corrosion resistant than their polycrystalline cousins of equivalent composition. Amorphous alloys are hard and can be used in areas where both resistance to wear and corrosion are simultaneously needed. For example the typical Vickers hardness of the polycrystalline Alloy 22 (N06022) is 250 but the Vickers hardness of an amorphous material is higher than 1000 [5]. When amorphous alloys partially or fully recrystallize, they may lose some of their characteristic corrosion resistance. This process is called devitrification [6]. The fact that amorphous materials are highly corrosion resistant is generally attributed to the absence of crystalline defects in the alloy; however the actual mechanism of this resistance is still not fully understood [1].

Iron (Fe) based alloys such as austenitic stainless steels containing approximately $18 \%$ chromium $(\mathrm{Cr})$ are widely used in the industry due to their corrosion resistance characteristics. 
However, polycrystalline Types 304 and 316 stainless steels are not as corrosion resistant as other polycrystalline alloys such as the nickel (Ni)-based Hastelloy C-22 alloy (Table 1) [7]. On the other hand, Fe-based amorphous alloys have even higher localized corrosion resistance than Alloy C-22 [8]. Since the iron based amorphous alloys are more economical to produce than the highly corrosion resistant nickel based alloys, its use seems attractive just for economical reasons.

Recently, Fe-based amorphous alloys have been produced in bulk compositions so they can be applied to the fabrication of many large structural components, including oceanic shipbuilding, nuclear, and oil and gas industries. These alloys are called structural amorphous metals or SAM by DARPA (Defense Advanced Research Projects Agency). Fe is a desirable base element for alloys that may be used in large industrial applications not only because $\mathrm{Fe}$ is inexpensive but also because Fe-based bulk metallic glasses have a high glass forming ability, high mechanical properties and soft magnetic properties. [9] The newer Fe-based amorphous alloys can be produced at relatively slow cooling rates in the order of 100 Kelvin per second [10]. This allows the production of bulk amorphous metals tailored to specific applications using processes such as thermal spray. Fe-based amorphous alloys such as SAM2X5 may contain up to $15 \%$ (atomic) in boron (B), which make them attractive for nuclear applications as neutron absorbing structural material [11]. SAM2X5 is a candidate material for neutron absorption applications and a candidate to replace both borated stainless steels and recently developed nickel-chromium-molybdenum-gadolinium (Ni-CrMo-Gd) alloys. Another Fe-based amorphous (SAM1651) alloy contains larger amount of molybdenum (Mo) for enhanced corrosion resistance [12].

It has been reported that coatings of both SAM2X5 and SAM1651 on 316 SS substrates resisted corrosion in the salt fog chamber test [5]. Small rust spots were attributed to the presence of partially devitrified regions of the coating. The aim of the current study was to present results regarding the performance of Fe-based SAM2X5 amorphous alloys during anodic polarization in hot concentrated salt solutions and in the salt fog test.

\section{ENVIRONMENTS}

The development of a new alloy or product generally has a targeted application. This is also the case of the SAM alloys. Currently envisioned applications include highly saline solutions where wear resistance is also required and environments that could be related to the neutron absorption industry. For the first case, it may be of interest to determine the behavior of the SAM alloys in high chloride environments that could simulate the behavior of seawater, for example. In the second case, it could be used as a basket material for the long-term disposition of nuclear waste.
One of the most aggressive solutions for stainless materials (such as the iron-based stainless steels and the nickel-based stainless containing chromium and molybdenum) are highly concentrated hot chloride solutions. The high chloride hot solutions tend to induce localized corrosion in the form of pitting and crevice corrosion into the naturally passivated alloys. These austenitic alloys passivate by the formation of a protective chromium oxide film on the surface. That is, chromium oxide is not protective in presence of hot chloride brines. A base solution of $1 \mathrm{M} \mathrm{NaCl}$ is used in many ASTM standards to compare for example the behavior of multiple stainless steels. Recently, more aggressive solutions have been used to compare the behavior of more highly corrosion resistant alloys. This solution is $5 \mathrm{M}$ (molar) calcium chloride $\left(\mathrm{CaCl}_{2}\right)$, which boils at temperatures higher than $120^{\circ} \mathrm{C}$. This $\mathrm{CaCl}_{2}$ solution is more than ten times richer in chloride than seawater and has a concentration of $40 \% \mathrm{CaCl}_{2}$ by weight of solution. Calcium based brines may also be more detrimental for the corrosion resistance of stainless alloys than sodium based brines.

Another electrolyte solution of interest is related to the long term disposal of highly radioactive nuclear waste is concentrated ground water. When ground water from the vicinity of Yucca Mountain (NV) is concentrated approximately 1000 times using evaporation, it becomes a carbonate/bicarbonate-rich brine. The original ground water was labeled J-13 and the resulting 1000-times concentrated brine was called simulated concentrated water or SCW. The approximate composition of SCW is (3.4 g/L potassium, 40.9 $\mathrm{g} / \mathrm{L}$ sodium, $1.4 \mathrm{~g} / \mathrm{L}$ fluoride, $6.7 \mathrm{~g} / \mathrm{L}$ chloride, $6.4 \mathrm{~g} / \mathrm{L}$ nitrate, $16.7 \mathrm{~g} / \mathrm{L}$ sulfate, $70 \mathrm{~g} / \mathrm{L}$ carbonate/bicarbonate and $\sim 40 \mathrm{mg} / \mathrm{L}$ silicate). That is, SCW is a multi-ionic solution containing aggressive species as chloride and beneficial species as nitrate. The weight percent concentration of salts in SCW is approximately $13 \%$. One of the forms by which ground water may enter in contact with the nuclear waste is by seepage or dripping onto the engineered barriers containing the waste from the drift walls. After many of thousands of years, the external and internal wall of the containers may be breached by corrosion, allowing seepage water to ingress into the container and enter in contact with the basket material and the radioactive material. This may cause the radioactive material to be transported by the water away from the emplacement site. At this point it is envisioned that the waters will be dilute and at low temperature (i.e. well below $50^{\circ} \mathrm{C}$ ). This last scenario represents what is called the "in package chemistry".

\section{EXPERIMENTAL}

Two types of experiments were performed; the cyclic potentiodynamic polarization (CPP) (ASTM G 61) and salt fog testing (ASTM B 117). For the CPP tests the tested specimens were four polycrystalline alloys: (a) Alloy 22 (N06022), (b) Ni- 
Cr-Mo-Gd Alloy (N06464), (c) Borated Type 304B SS (S30466) and one amorphous alloy in ribbon form (d) SAM2X5. The compositions of the alloys are in Table 1 . The Alloy 22 specimens were multiple crevice assemblies (MCA) described before [13] and the Ni-Gd and the 304B SS material were non-creviced prisms similar to the specimens described in ASTM G 5 [14]. The area of test specimens of these three bulk materials ranged from 7.43 to $14.4 \mathrm{~cm}^{2}$. The SAM2X5 alloy was a small ribbon approximately $20 \mathrm{~mm}$ long, $1 \mathrm{~mm}$ wide and $25 \mu \mathrm{m}$ thick. The test area of the ribbons was approximately 0.4 $\mathrm{cm}^{2}$. The SAM2X5 material was prepared by dropping molten metal on a water-cooled copper spinning wheel in an inert atmosphere. The initial metal temperature was $1050^{\circ} \mathrm{C}$ and the wheel was spinning at $17.4 \mathrm{~m} / \mathrm{sec}$. The fast cooling fabrication process made the material amorphous. The ribbon had two sides; the side that contacted the spinning wheel was slightly darker and contained small dent-like features and the side that faced away from the wheel was smoother and shinier.

CPP tests were carried in two electrolyte solutions: (1) $5 \mathrm{M} \mathrm{CaCl}_{2}$ at $105^{\circ} \mathrm{C}$ and (2) SCW at $90^{\circ} \mathrm{C}$. The ambient temperature $\mathrm{pH}$ of the solutions was 5 to 6 for the $\mathrm{CaCl}_{2}$ solution and 8 to 10 for the SCW solution. Nitrogen $\left(\mathrm{N}_{2}\right)$ was purged through the solution overnight (usually 24 hours) while the corrosion potential $\left(\mathrm{E}_{\text {corr }}\right)$ of the test specimen was monitored. Nitrogen bubbling was continued throughout all the electrochemical tests. The electrochemical tests were conducted in a one-liter, three-electrode, borosilicate glass flask (ASTM G 5). A water-cooled condenser combined with a water trap was used to avoid evaporation of the solution and to prevent the ingress of air (oxygen). The temperature of the solution was controlled using a heating mantle connected to a temperature control device. All the tests were carried out at ambient pressure. The reference electrode was saturated silver chloride (SSC) electrode, which has a potential of $199 \mathrm{mV}$ more positive than the standard hydrogen electrode (SHE). The reference electrode was connected to the solution through a water-jacketed Luggin probe so that the electrode was maintained at near ambient temperature. The counter electrode was a flag $\left(\sim 40 \mathrm{~cm}^{2}\right)$ of platinum foil spot-welded to a platinum wire. All the potentials in this paper are reported in the SSC scale. In the CPP test, the potential scan was started approximately $100 \mathrm{mV}$ below $\mathrm{E}_{\text {corr }}$ at a set scan rate of 0.167 $\mathrm{mV} / \mathrm{s}$. The scan direction was reversed when the current density usually reached $5 \mathrm{~mA} / \mathrm{cm}^{2}$ in the forward scan.

Amorphous metallic alloy coupons were especially prepared for salt fog testing. A liquid metallic solution of desired composition (SAM2X5) (Table 1) was first atomized in an inert atmosphere to produce a fine powder or amorphous particles (e.g. 50- $\mu \mathrm{m}$ diameter) and then the powder was thermally sprayed onto the test coupons. That is, the coupons exposed to the salt fog had a coating of the amorphous alloys over a polycrystalline metallic substrate of 316L SS. Coating was done using the high-velocity oxy-fuel (HVOF) process.
This technique minimizes the amount of porosity in the coating (increases its density). The 316L SS coupons were 4-inch $\mathrm{x} 4$ inch $x$ 1/4-inch thick. The amorphous coating on the coupons was nominally 15 mils (or $380 \mu \mathrm{m}$ ) thick. Witness materials were also tested along with the amorphous materials in the salt fog test. The witness materials included (a) Carbon Steel 1018 and (b) Alloy C-22 (Table 1).

Salt fog or salt spray testing has been performed according to the guidelines in ASTM B 117 [14]. This test is excellent to detect the presence of alpha-ferrite, which is always present if devitrification occurs. Hence, if rusting does not occur on the exposed coupons it means that the coating is fully amorphous. The salt fog apparatus was 94-inch long, 35-inch wide and 56inch high and the test chamber was 50-inch L x 29-inch W x 25-inch $\mathrm{H}$. The chamber can create a variety of environments by cycling automatically between salt fog, high humidity, and low humidity with dry-off, dwell and ambient conditions in any combination and for any length of time. The specific test performed for the reported results corresponded to the accelerated 24-h GM cycle (Table 2). The coupons were attached to a fiberglass bracket in the chamber using nylon bolts and nuts through the center holes of the coupons. This procedure kept each specimen electrically isolated from the surroundings. Because the edges of the coupons are sometimes not well coated, they were covered with silicone before they were introduced into the test chamber.

Table 1. Typical Alloy Compositions

\begin{tabular}{|c|c|c|}
\hline $\begin{array}{c}\text { Alloy } \\
\text { Designation }\end{array}$ & $\begin{array}{l}\text { Approximate } \\
\text { Composition } \\
\text { A - Weight \% } \\
\text { B - Atomic \% }\end{array}$ & Description \\
\hline $1018 \mathrm{CS}$ & 99Fe-0.18C-0.8Mn ${ }^{A}$ & UNS G10180 \\
\hline 316L SS & $\begin{array}{l}\text { 70Fe-18Cr-10Ni- } \\
2.5 \mathrm{Mo}{ }^{\mathrm{A}}\end{array}$ & $\begin{array}{l}\text { S31603 } \\
\text { ASTM A } 240\end{array}$ \\
\hline Alloy 22 & $\begin{array}{l}\text { 57Ni-22Cr-13Mo- } \\
3 \mathrm{~W}-3 \mathrm{Fe}\end{array}$ & $\begin{array}{l}\text { N06022 } \\
\text { ASTM B } 575\end{array}$ \\
\hline $\begin{array}{l}\text { Borated } \\
\text { 304B SS }\end{array}$ & Fe-19Cr-14Ni-1.6B & $\begin{array}{l}\text { S30466 } \\
\text { ASTM A } 887\end{array}$ \\
\hline Ni-Gd Alloy & Ni-16Cr-15Mo-2Gd & $\begin{array}{l}\text { N06464 } \\
\text { ASTM B } 932\end{array}$ \\
\hline SAM2X5 & $\begin{array}{l}\text { 58.4Fe-18.5Cr-3.2B- } \\
\text { 14Mo-1C-1.3Si-2Mn- } \\
5.8 \mathrm{~W}^{\mathrm{A}}\end{array}$ & $\begin{array}{l}\text { Sprayed coating } \\
\text { Amorphous }\end{array}$ \\
\hline SAM2X5 & $\begin{array}{l}\text { 49.7Fe-18.1Cr-15.2B- } \\
\text { 7.4Mo-3.8C-2.4Si- } \\
1.9 \mathrm{Mn}-1.6 \mathrm{~W}^{\mathrm{B}}\end{array}$ & $\begin{array}{l}\text { Ribbon } \\
\text { Amorphous }\end{array}$ \\
\hline
\end{tabular}


Table 2. 24-h Cycle in the Accelerated Salt Fog Corrosion Test

\begin{tabular}{|c|c|c|}
\hline Shift & $\begin{array}{l}\text { Elapsed } \\
\text { Time } \\
\text { (h) }\end{array}$ & Event \\
\hline \multirow{4}{*}{$\begin{array}{l}\text { Ambient } \\
\text { Soak }\end{array}$} & 0 & $\begin{array}{l}\text { Salt solution mist for } 30 \mathrm{~s} \text { followed } \\
\text { by ambient exposure }\left(13-28^{\circ} \mathrm{C}\right)\end{array}$ \\
\hline & 1.5 & $\begin{array}{l}\text { Salt solution mist for } 30 \mathrm{~s} \text { followed } \\
\text { by ambient exposure }\left(13-28^{\circ} \mathrm{C}\right)\end{array}$ \\
\hline & 3 & $\begin{array}{l}\text { Salt solution mist for } 30 \mathrm{~s} \text { followed } \\
\text { by ambient exposure }\left(13-28^{\circ} \mathrm{C}\right)\end{array}$ \\
\hline & 4.5 & $\begin{array}{l}\text { Salt solution mist for } 30 \mathrm{~s} \text { followed } \\
\text { by ambient exposure }\left(13-28^{\circ} \mathrm{C}\right)\end{array}$ \\
\hline $\begin{array}{l}\text { Wet } \\
\text { Soak }\end{array}$ & $8-16$ & $\begin{array}{l}\text { 8-h high humidity exposure ( } 49 \pm 0.5 \\
{ }^{\circ} \mathrm{C} \text { at } 100 \% \mathrm{RH} \text { ) including } 55 \mathrm{~min} \\
\text { ramp to wet conditions }\end{array}$ \\
\hline $\begin{array}{l}\text { Dry } \\
\text { Soak }\end{array}$ & $16-24$ & $\begin{array}{l}\text { 8-h dry exposure }\left(60 \pm 0.5^{\circ} \mathrm{C} \text { at }\right. \\
<30 \% \text { RH) including } 175 \mathrm{~min} \text { ramp to } \\
\text { dry conditions }\end{array}$ \\
\hline \multicolumn{3}{|c|}{$\begin{array}{l}\text { The salt solution mist was } 1.25 \% \text { by weight }(0.9 \% \mathrm{NaCl}+ \\
\left.0.1 \% \mathrm{CaCl}_{2}+0.25 \% \mathrm{NaHCO}_{3}\right)\end{array}$} \\
\hline
\end{tabular}

\section{RESULTS}

\section{Anodic Potentiodynamic Polarization}

Cyclic potentiodynamic polarization behavior of several alloys of interest was studied in $5 \mathrm{M} \mathrm{CaCl}_{2}$ at $105^{\circ} \mathrm{C}$ and SCW at $90^{\circ} \mathrm{C}$. The tested alloys were SAM2X5 ribbon, Alloy 22 (N06022), Ni-Gd alloy (N06464) and a type 304B6 SS borated stainless steel (S30466) (Table 1).

Figure 1 shows the CPP curves in $5 \mathrm{M} \mathrm{CaCl}_{2}$ at $105^{\circ} \mathrm{C}$. It is apparent from Figure 1 that there are two groups of alloys regarding their anodic behavior in the hot concentrated calcium brine. One group includes the three polycrystalline alloys (Alloy 22, Ni-Gd and Borated SS) and the other group includes the only tested amorphous alloy (SAM2X5). For all the polycrystalline alloys, the breakdown potential was lower than $0 \mathrm{mV}$ and for SAM2X5 the breakdown potential was nearly $800 \mathrm{mV}$.

Figure 1 shows that the anodic region of the polarization curve for the borated 304B SS had a narrow pseudo-passive region of potentials (less than $100 \mathrm{mV}$ wide) for which the current density was between $10^{-7}$ and $10^{-6} \mathrm{~A} / \mathrm{cm}^{2}$. After this narrow passive region the current increased rapidly due to massive dissolution of the specimen. In the reverse scan the specimen did not repassivate (i.e. there was no cross-over) even though the potential was lowered to its original corrosion potential (Figure 1). Figure 2 shows that the borated stainless steel did not suffer typical localized corrosion but a massive attack on its entire surface. It appears that the passive film covering the surface of the specimen rapidly dissolved in the hot concentrated chloride brine, in spite that the maximum applied potential was only $-250 \mathrm{mV}$ SSC (Figure 1). Figure 2.b shows that dimples and cavities of less than $5 \mu \mathrm{m}$ diameter formed on the surface of the specimen after the anodic polarization test. It is apparent that these dimples may have contained the borides in the alloy. Some of the dimples still appear to contain residual boride particles. It has been reported before that the borides do not dissolve in the corroding brine but remain on the surface after the matrix dissolved around them [15]. Even though the boride itself may not dissolve, the attack may have initiated in the boundary between the boride and the matrix.

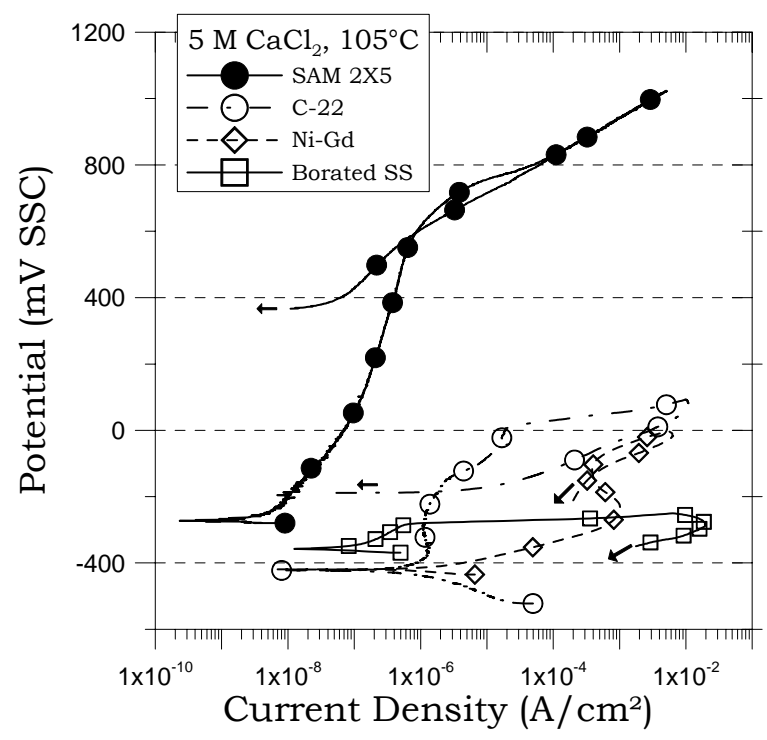

Figure 1. Anodic behavior for four materials in $5 \mathrm{M} \mathrm{CaCl}_{2}$ at $105^{\circ} \mathrm{C}$

The anodic CPP curve for the Ni-Gd alloy did not show a typical passive region above the corrosion potential (Figure 1). That is, from the corrosion potential the current density increased continuously as the potential increased. The CPP curve showed an anodic peak of $10^{-3} \mathrm{~A} / \mathrm{cm}^{2}$ at approximately $-225 \mathrm{mV}$ SSC and then the current slightly decreased to values between $10^{-3}$ to $10^{-4} \mathrm{~A} / \mathrm{cm}^{2}$ before the final breakdown increase. The maximum applied potential for the Ni-Gd alloy was $0 \mathrm{mV}$ SSC or approximately $250 \mathrm{mV}$ higher than that for the borated 304B SS. 


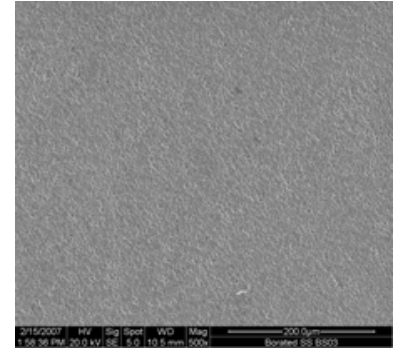

2.a - Magnification X500

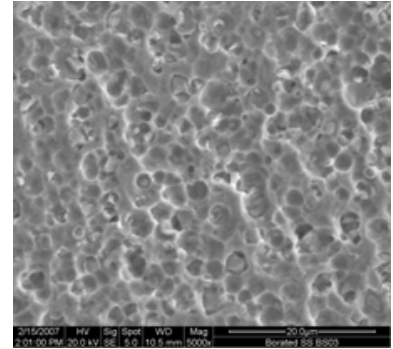

2.b - Magnification X5000
Figure 2. Surface of borated 304B SS after CPP in $5 \mathrm{M} \mathrm{CaCl}_{2}$ at $105^{\circ} \mathrm{C}$

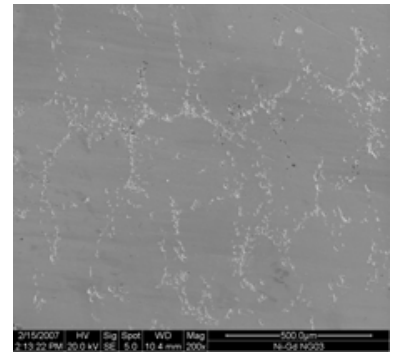

3.a - Magnification X200

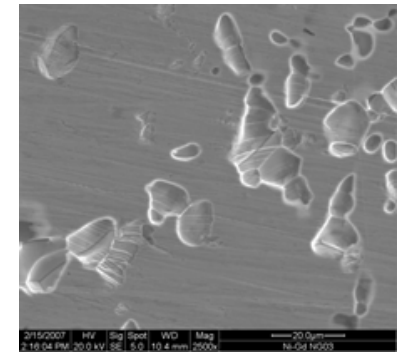

3.b - Magnification X2500
Figure 3. Surface of Ni-Gd Alloy after CPP in $5 \mathrm{M} \mathrm{CaCl}_{2}$ at $105^{\circ} \mathrm{C}$

Figure 3 shows that the corrosion attack on the surface of the Ni-Gd alloy was not uniform but it etched grain boundaries or areas of material segregation in the alloy. Figure 3.b shows a high magnification image of the darkened areas in Figure 3.a. Each one of the cavities observed on the surface may have corresponded to areas where secondary phase gadolinides particles $\left(\mathrm{Ni}_{5} \mathrm{Gd}\right)$ existed. The particles dissolved preferentially in the hot concentrated brine leaving behind the more corrosion resistant Ni-Cr-Mo matrix. This phenomenon has been reported before [16]. It has also been reported that if a second consecutive scan is carried out using a pre-corroded Ni-Gd specimen, lower current densities will be measured for this second scan because the $\mathrm{Ni}_{5} \mathrm{Gd}$ particles already dissolved in the first scan and the remaining matrix is more resistant to polarization and corrosion [16].

The CPP curve of Alloy 22 (specimen DEA3168) in $5 \mathrm{M}$ $\mathrm{CaCl}_{2}$ at $105^{\circ} \mathrm{C}$ is similar to that of the borated 304B SS (Figure 1). That is, the CPP curve for Alloy 22 showed a passive-like behavior followed by a fast increase in the current due to passivity breakdown. The pseudo-passive region of potentials range was approximately $400 \mathrm{mV}$ wide, for which the current density varied between $10^{-6}$ and $10^{-5} \mathrm{~A} / \mathrm{cm}^{2}$. After this pseudo-passive region the current density increased abruptly by the massive attack of the specimen surface. The maximum applied potential for the Alloy 22 specimen was less than $100 \mathrm{mV}$ SSC. In spite of this massive attack, and unlike the 304B SS, the Alloy 22 specimen repassivated in the reverse scan at a potential higher than the initial corrosion potential. Figure 4 shows the appearance of the Alloy 22 specimen (DEA3168) after the CPP test in $5 \mathrm{M} \mathrm{CaCl}_{2}$ at $105^{\circ} \mathrm{C}$. The darker gray band in Figure 4.a corresponds to the massive attack that the specimen suffered due to anodic polarization in the hot concentrate chloride solution. The attack occurred outside the crevice former. A higher magnification of the attacked area (Figure 4.b) shows the uneven intergranular appearance of the attack. That is, grain boundaries were preferentially dissolved.

The CPP curve for the SAM2X 5 material in $5 \mathrm{M} \mathrm{CaCl}_{2}$ at $105^{\circ} \mathrm{C}$ was different from the four other polycrystalline tested materials (Figure 1). The passive region for the SAM2X5 alloy was more than $800 \mathrm{mV}$ wide where the current density varied between $10^{-8}$ to $10^{-6} \mathrm{~A} / \mathrm{cm}^{2}$. For the amorphous SAM2X5 the potential breakdown was gradual due to oxygen evolution on the surface of the tested specimen and not due to massive corrosion of the surface as the polycrystalline specimens showed. The highest applied potential for the SAM2X5 alloy was more than 1,000 $\mathrm{mV} \mathrm{SSC}$, which is beyond the potential for the stability of water. Figure 5 shows the appearance of the SAM2X5 specimen after the CPP test in $5 \mathrm{M} \mathrm{CaCl}_{2}$ at $105^{\circ} \mathrm{C}$.

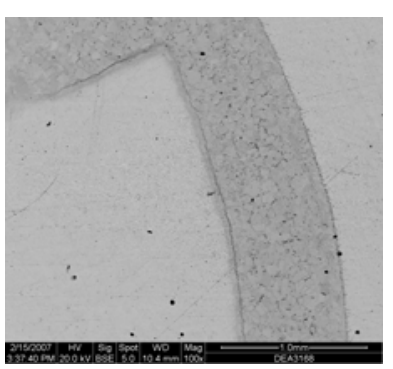

4.a - Magnification X100

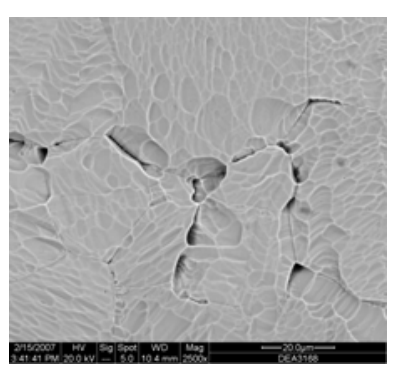

4.b - Magnification X2500
Figure 4. Surface of Alloy $22 \mathrm{DEA} 3168$ after CPP in
\[ 5 \mathrm{M} \mathrm{CaCl}_{2} \text { at } 105^{\circ} \mathrm{C} \]

Figures 5.a and 5.b show the characteristic of the surface on the darker or rougher side of the specimen and Figures 5.c and 5.d of the smoother or shinier side of the specimen. Figures 5.a and 5.c are lower magnification representations and Figures 5.b and 5.d are high magnifications. It is clear that the forced dissolution of the SAM2X5 material progressed in a uniform way. Unlike any of the other three polycrystalline materials, the dissolution of the SAM2X5 material did not show a preferential attack of any special feature in the alloy (Figures 5.b and 5.d). This is because the material is fully amorphous without precipitates (like the 304B SS and Ni-Gd alloy) or without grain boundaries like the three other tested alloys. Figure 5.c 
shows two circle-like features on the surface of the alloy. They represent the location of small bubbles ( $200 \mu \mathrm{m}$ diameter) that were sitting on the specimen surface during the polarization test. Due to the high applied potentials in the anodic polarization, the material around the bubbles dissolved uniformly and the area covered by the bubbles was left uncorroded. Figure 5.d shows clearly the step formed on the surface of the specimen due to this phenomenon. It seems apparent that the depth of dissolution was in the order of $2 \mu \mathrm{m}$.

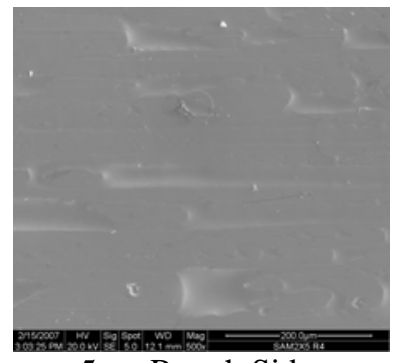

5.a - Rough Side: Magnification X500

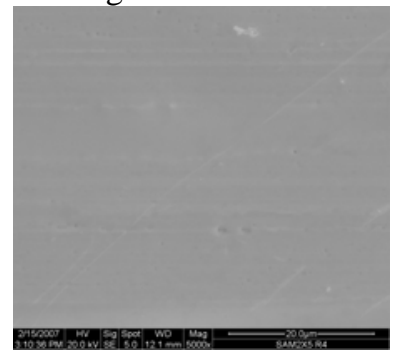

5.b - Rough Side: Magnification X5000

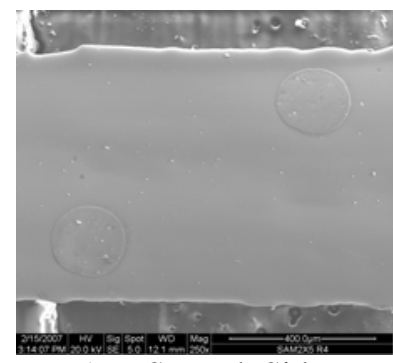

5.c - Smooth Side: Magnification X250

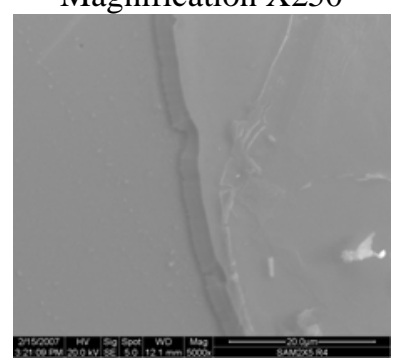

5.d - Smooth Side: Magnification X5000

\section{Figure 5. Surface of Amorphous Alloy SAM2X5 after $\mathrm{CPP}$ in $5 \mathrm{M} \mathrm{CaCl}_{2}$ at $105^{\circ} \mathrm{C}$}

Figure 6 shows the CPP tests in SCW at $90^{\circ} \mathrm{C}$. Unlike the behavior of the tested materials in $5 \mathrm{M} \mathrm{CaCl}_{2}$ at $105^{\circ} \mathrm{C}$, the behavior in the SCW solution was similar for all of the tested alloys. Just above the corrosion potential, the four materials showed a primary pseudo-passive region of potentials, an intermediate anodic peak and a secondary pseudo-passive region of potentials before the final potential breakdown probably induced by water decomposition (evolution of oxygen) and transpassive dissolution or some of the alloying elements. The two Ni-based alloys (Ni-Gd and Alloy 22) showed the anodic peak at the lowest potential (Figure 6) and the two Fe-based materials (304B SS and SAM2X5) had the anodic peak at a higher potential. The current density at the peak peak was higher for the Fe-based materials than for the Ni-based materials. The presence of the anodic peak for tests performed in hot SCW solution has been reported before [1719]. The occurrence of the anodic peak depends on the temperature and the $\mathrm{pH}$ of the solution and its existence was attributed to secondary oxidation of elements present in the passive film [17-19].

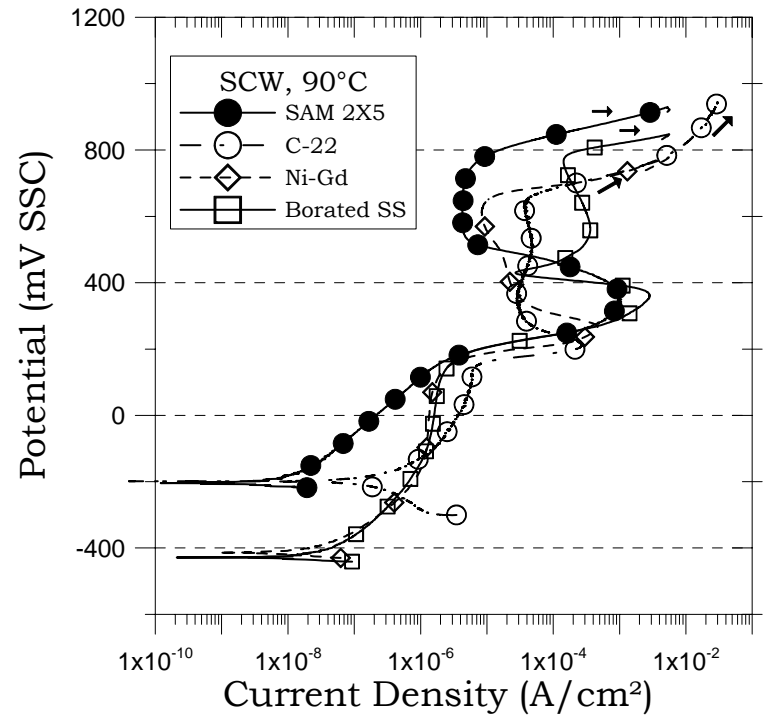

Figure 6. Cyclic Potentiodynamic Polarization (CPP) of four materials in SCW at $90^{\circ} \mathrm{C}$.

SCW is a less aggressive solution than $5 \mathrm{M} \mathrm{CaCl}_{2}$, therefore the polarization curves of the four tested materials do not look too different from each other. However, Figure 6 shows that the lowest passive current density both in the primary and secondary region of potentials was the lowest for the SAM2X5 material. Observation of the specimens after the tests showed generalized corrosion for both SAM2X5 and Alloy 22 materials with a thicker oxide film formed on the surface than in $5 \mathrm{M} \mathrm{CaCl}_{2}$ at $105^{\circ} \mathrm{C}$. The Ni-Gd and 304B SS materials suffered preferential attack around the precipitated particles (gadolinides or borides) similarly as shown in Figures 2.b and 3.b.

\section{The Breakdown Potential}

The breakdown potential is the potential for which the current density increases rapidly due to passivity breakdown during a CPP test. In most cases this increase in current is obvious (such as for 304B SS in Figure 1) but in some cases the potential for current increase is less defined (such as for Ni-Gd alloy in Figure 1). To circumvent this obstacle, it is generally used E20 to represent the breakdown potential [20]. E20 represents the potential for which the current density in the forward scan of a CPP reaches $20 \mu \mathrm{A} / \mathrm{cm}^{2}$. The lower the value of E20 the less resistant is the alloy to passivity breakdown. 
Figure 7 shows the breakdown potential E20 for the tested alloys in $5 \mathrm{M} \mathrm{CaCl}_{2}$ at $105^{\circ} \mathrm{C}$ (Data from Figure 1). The lowest breakdown potential corresponded to the Ni-Gd alloy and the highest for SAM2X5. There is more than $1000 \mathrm{mV}$ separation between the least resistant alloy (Ni-Gd) to passivity breakdown and the highest resistant alloy (SAM2X5). The most resistant polycrystalline alloy was Alloy 22, however its breakdown potential was approximately $800 \mathrm{mV}$ lower than the breakdown potential for the amorphous alloy SAM2X5.

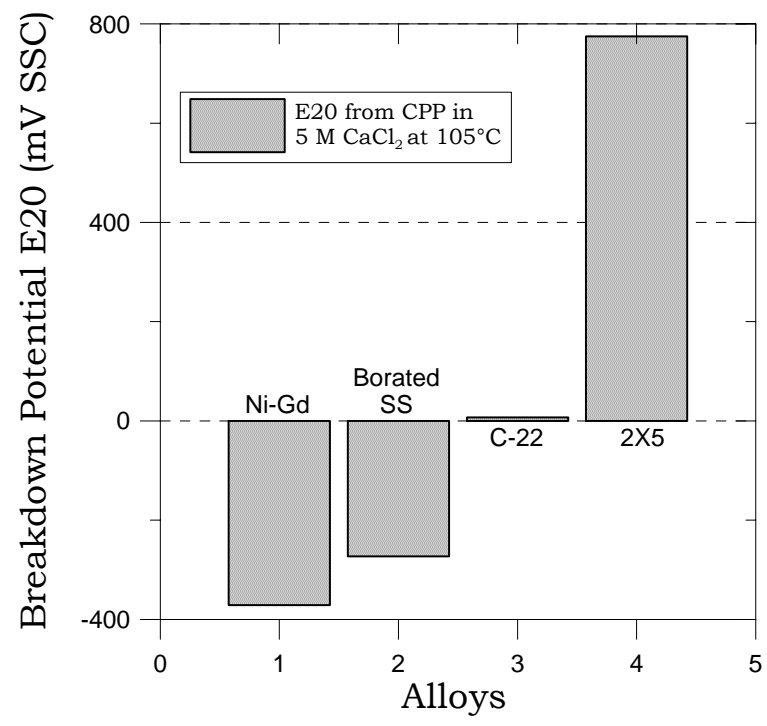

Figure 7. Breakdown potentials E20 from CPP tests in $5 \mathrm{M} \mathrm{CaCl}_{2}$ at $105^{\circ} \mathrm{C}$

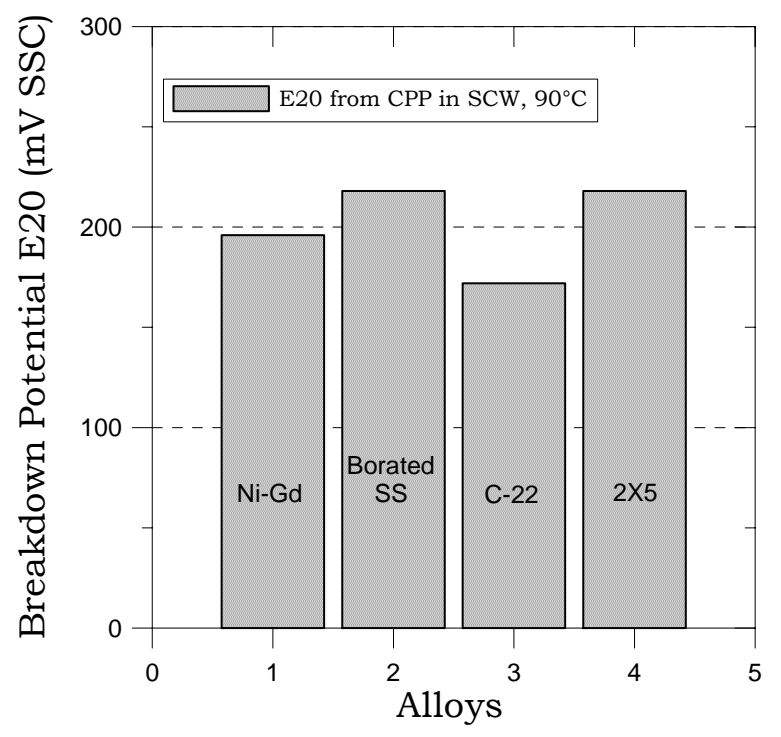

Figure 8. Breakdown potentials E20 from CPP tests in SCW at $90^{\circ} \mathrm{C}$.
Figure 8 shows the breakdown potential E20 for the tested alloys in SCW at $90^{\circ} \mathrm{C}$ (Data from Figure 6). The breakdown potentials for the four alloys was similar and in the vicinity of $200 \mathrm{mV}$ SSC. The lowest E20 values corresponded to the $\mathrm{Ni}$ based alloys which had the lowest potentials for the anodic current density peaks (Figure 6). The lowest breakdown potential corresponded to Alloy 22, probably due to its high content of Mo and W, which do not offer high resistance to oxidation in the alkaline SCW environment.

\section{Salt Fog Testing}

Coupons of Alloy 22 and 316LSS were coated with amorphous alloy SAM2X5 powder using the HVOF process. The coupons were $4 \times 4 \times 1 / 4$-inch. There were 10 substrate coupons of Alloy 22 and 10 substrate coupons of 316L SS. They were all coated with SAM2X5. The coating was performed at Plasma Technology Inc. (Torrance, CA). The salt fog testing (ASTM B 117) was performed at E-Labs (Fredericksburg, VA). The coupons were exposed to 8 cycles each one of 24 hours (Table 2). For reference purposes, five coupons ( $2 \times 2 \times 1 / 8$-inch) of uncoated 1018 carbon steel and three coupons ( $2 \times 2 \times 1 / 8$-inch) of uncoated Alloy 22 were included in the salt fog chamber. The coated Alloy 22 coupons were labeled C17 to C21 and W17 to W21. The coated 316L SS coupons were labeled C3 to C7 and W3 to W6, W8 and W9. The non-coated 1018 CS coupons were labeled A11-A15 and the non-coated Alloy 22 coupons were labeled CC22-4058 to CC22-4060.

After the tests, most of the coated coupons developed a small number of pinpoint size rust spots. For the ten coated 316L SS coupons, the fewer number of rust spots was one (1) for coupon W8 and the largest amount of rust spots was 23 for the coupon C6. Figure 9 shows coupon C3 after 8 full 24-h cycles in the salt fog chamber (Table 2). Arrows indicated the presence of 10 pinpoint rust spots. The average number of rust spots for the ten 316L SS coated coupons was $9.6 \pm 7.6$. For the ten coated Alloy 22 coupons, the fewer number of rust spots was zero for coupon W21 and the largest amount of rust spots was 14 for coupons W18 and W20. Figure 10 shows coupon C19 after 8 full 24-h cycles in the salt fog chamber (Table 2). Arrows indicated the presence of 10 pinpoint rust spots. The average number of rust spots for the ten Alloy 22 coated coupons was $6.7 \pm 4.9$.

The non-coated 1018 CS witness coupons fully rusted during the 8 full 24-h cycles in the salt fog chamber. None of the non coated Alloy 22 witness coupons suffered any type of corrosion. It is apparent that the pinpoint rust spots are formed on the coating. The pinpoint rust spots always form at the top of pimples that developed in the coating during the HVOF deposition process. The pimples have the appearance of a 
micro-volcano. The actual origin rust spot is much smaller than what it is seen on the coupons after the test. That is, a micro area of products in the volcano crater seems to rust and the corrosion product spills over the sides causing the pinpoint rust spot described above. Current efforts include the cross sectioning of the coated specimens to determine the depth of the attack at the rust spots. It is likely that this is only a surface phenomenon and that it does not affect the interface between the substrate and the coating. Future tests also should determine if the rust spots are a result of partial devitrification and the formation of a ferrite phase at the pimple spots.

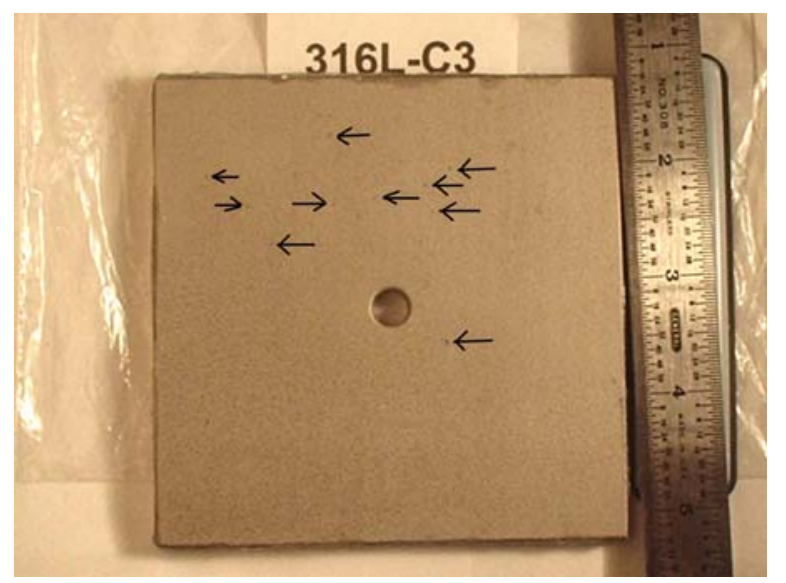

Figure 9. Coated coupon C3 after 8 full 24-h cycles in the salt fog test. Arrows show 10 pinpoint rust spots.

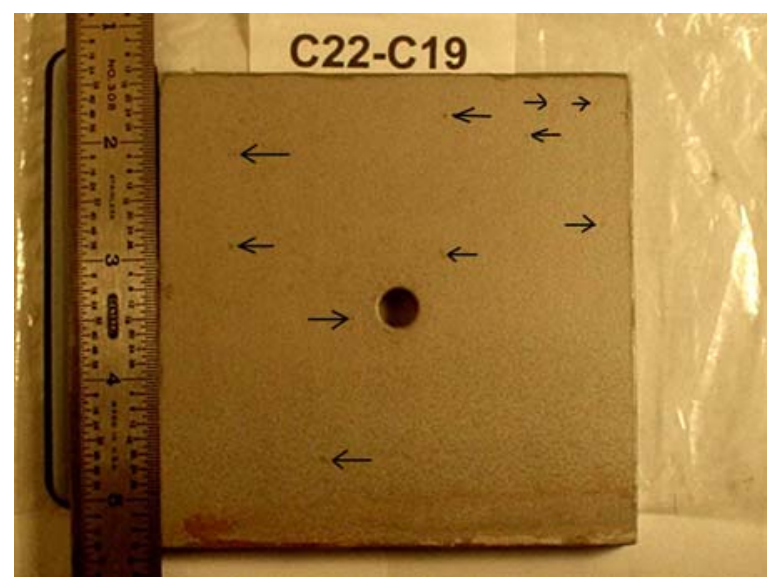

Figure 10. Coated coupon C19 after 8 full 24-h cycles in the salt fog test. Arrows show 10 pinpoint rust spots.

\section{SUMMARY AND CONCLUSIONS}

Amorphous Alloys were tested for corrosion resistance both in the fast-cooled ribbon form and as spray coatings

- Iron-based amorphous alloys are extremely resistant to localized corrosion in hot concentrated chloride solutions

- When forced to corrode in the highly aggressive $5 \mathrm{M} \mathrm{CaCl}_{2}$ at $105^{\circ} \mathrm{C}$, the $\mathrm{SAM} 2 \mathrm{X} 5$ amorphous material dissolved uniformly, unlike the polycrystalline materials that were attacked at grain boundaries and at precipitate edges

- SAM2X5 can be deposited as an amorphous coating on other substrate engineering alloys

- Salt fog-testing showed good resistance to corrosion of the coated alloy. Pinpoint rust spots could be result of micro partial devitrification.

\section{ACKNOWLEDGMENTS}

The technical expertise of Jor-Shan Choi, Robert Bayles and Jeffery Haslam is gratefully acknowledged. This work was partially performed under the auspices of the U. S. Department of Energy by the University of California Lawrence Livermore National Laboratory under contract W-7405-Eng-48. Work was sponsored by the United States Department of Energy (DOE), Office of Civilian Radioactive Waste Management (OCRWM) and the Defense Advanced Research Projects Agency (DARPA), Defense Science Office (DSO). The guidance of Leo Christodoulou at DARPA DSO and of Jeffrey Walker at DOE OCRWM is gratefully acknowledged.

\section{DISCLAIMER}

This document was prepared as an account of work sponsored by an agency of the United States Government. Neither the United States Government nor the University of California nor any of their employees, makes any warranty, express or implied, or assumes any legal liability or responsibility for the accuracy, completeness, or usefulness of any information, apparatus, product, or process disclosed, or represents that its use would not infringe privately owned rights. Reference herein to any specific commercial product, process, or service by trade name, trademark, manufacturer, or otherwise, does not necessarily constitute or imply its endorsement, recommendation, or favoring by the United States Government or the University of California. The views and opinions of authors expressed herein do not necessarily state or reflect those of the United States Government or the University of California, and shall not be used for advertising or product endorsement purposes. 


\section{REFERENCES}

1. J. R. Scully and A. Lucente, "Corrosion of Amorphous Metals,” ASM Handbook, Volume 13B, Corrosion: Materials, p. 476 (ASM International, 2005: Materials Park, OH).

2. K. Hashimoto, K. Asami, M. Naka and T. Masumoto, Corr. Sci., 19, 857 (1979)

3. K. Asami, M. Naka, K. Hashimoto and T. Masumoto, J. Electrochem. Soc., 127, 76 (1991).

4. H. Habazaki, A. Kawashima, K. Asami and K. Hashimoto, J. Electrochem. Soc., 138, 2130 (1980).

5. R. B. Rebak, L. F. Aprigliano, S. D. Day, and J. C. Farmer, "Salt Fog Testing of Iron-Based Amorphous Alloys," Paper NN3.14, in proceedings of the symposium Scientific Basis for Nuclear Waste Management XXX in the Materials Research Society annual conference, 28 November to 01 December 2006, Boston MA.

6. J. R. Scully, A. Gebert and J. H. Payer, submitted for publication, 2006

7. R. B. Rebak and J. H. Payer, "Passive Corrosion Behavior of Alloy 22," in proceedings of the International High-Level Radioactive Waste Management -IHLRWM- Conference, p. 493, Las Vegas, NV April 30 to May 04, 2006, (American Nuclear Society, La Grange Park, IL).

8. J. C. Farmer, J. J. Haslam, S. D. Day, D. J. Branagan, C. A. Blue, J. D. K. Rivard, L. F. Aprigliano, N. Yang, J. H. Perepezko and M. B. Beardsley, "Corrosion Characterization of Iron-Based High-Performance Amorphous-Metal ThermalSpray Coatings," in proceedings of 2005 ASME PVP Conference 17-21 July 2005, Vol. 7, Operations, Applications and Components, p. 583 (New York, NY: ASME, 2005).

9. J. Shen, Q. Chen, J. Sun, H. Fan and G. Wang, Applied Physics Letters, 86, 151907 (2005).

10. L. Kaufman, J. H. Perepezko, and K. Hildal "Synthesis and Performance of Fe-Based Amorphous Alloys for Nuclear Waste Repository Applications," in proceedings of the Joint International Topical Meeting on Mathematics and Computation and Supercomputing in Nuclear Applications (M\&C + SNA), organized by the American Nuclear Society in Monterey, CA 15-19 April 2007.

11. T. Lian, S. D. Day, P. D. Hailey, J. S. Choi and J. C. Farmer, "Comparative Study on the Corrosion Resistance of Fe-Based Amorphous Metal, Borated Stainless Steel and NiCr-Mo-Gd Alloy," Paper NN8.7 in proceedings of the symposium Scientific Basis for Nuclear Waste Management XXX in the Materials Research Society annual conference, 28 November to 01 December 2006, Boston MA.

12. J. C. Farmer "Corrosion-Resistant Iron-Based AmorphousMetal Coatings,” Paper PVP2006-ICPVT11-93421 in the 2006 Pressure Vessels \& Piping Conference and the Eleventh International Conference on Pressure Vessel Technology, 2327 July 2006, Vancouver, BC, Canada.

13. R. B. Rebak, R. A. Etien, S. R. Gordon and G. O. Ilevbare, "Influence of Black Annealing Oxide Scale on the Anodic Behavior of Alloy 22,” Corrosion, 62, 11, 967, 2006

14. ASTM International, Volume 03.02, Standard B 117 "Standard Test Method of Salt Spray (Fog) Testing," (ASTM International, 2004: West Conshohocken, PA).

15. D. V. Fix, J. C. Estill, L. L. Wong and R. B. Rebak, "General and Localized Corrosion of Austenitic and Borated Stainless Steels in Simulated Concentrated Ground Waters," in Proceedings of the 2004 ASME Pressure Vessels and Piping Division Conference, July 25-29 2004, San Diego, CA, Vol. 483, pp. 121-130 (American Society of Mechanical Engineers, 2004: New York, NY)

16. T. E. Lister, R. E. Mizia, P. J. Pinhero, T. L. Trowbridge, and K. Delezene-Briggs, "Studies of the Corrosion Properties of Ni-Cr-Mo-Gd Neutron-Absorbin Alloys,” Corrosion, 61, 7, 706, 2005.

17. A. W. Szmodis, K. L. Anderson, J. C. Farmer, T. Lian, and C. A. Orme, "Characteristics of the Oxides Films formed on Alloy 22," in proceedings of the Scientific Basis for Nuclear Waste Management XXVI, Volume 757, p. 757 Edited by R. J. Finch and D. B. Bullen (Materials Research Society, 2003: Warrendale, PA).

18. K.T. Chiang, D.S. Dunn, and G.A. Cragnolino, "Effect of Simulated Groundwater Chemistry on Stress Corrosion Cracking of Alloy 22," Paper 05463 (NACE International, 2006: Houston, TX).

19. R. B. Rebak, K. J. Evans, and G. O. Ilevbare, "Crevice Repassivation Potentials for Alloy 22 in Simulated Concentrated Ground Waters,” Paper 07584 (NACE International, 2007: Houston, TX).

20. J. J. Evans, A. Yilmaz, S. Daniel Day, L. L. Wong, J. C. Estill and R. B. Rebak, "Using Electrochemical Methods to Determine Alloy 22's Crevice Corrosion Repassivation Potential,” Journal of Metals, Vol 57, pp. 56-61 (2005). 